\title{
Metod Dakwah dalam Pengislaman di Sabah (Sebelum Era Penguasaan British Crown Colony)
}

\section{Method of Da'wah in the Islamisation in Sabah (Before the Era of British Crown Colony)}

\author{
Abd Hadi Borham (Corresponding author) \\ Department of Islamic Studies, Faculty of Human Sciences, Universiti Pendidikan Sultan \\ Idris, 35900 Tanjung Malim, Perak, Malaysia. \\ abdhadi.borham@fsk.upsi.edu.my \\ Wahyu Hidayat Abdullah \\ Department of Islamic Studies, Faculty of Human Sciences, Universiti Pendidikan Sultan \\ Idris, 35900 Tanjung Malim, Perak, Malaysia. \\ wahyu@fsk.upsi.edu.my \\ Mohamad Marzuqi Abdul Rahim \\ Department of Islamic Studies, Faculty of Human Sciences, Universiti Pendidikan Sultan \\ Idris, 35900 Tanjung Malim, Perak, Malaysia. \\ marzuqi@fsk.upsi.edu.my
}

DOI: https://doi.org/10.22452/usuluddin.vol49no1.1

\begin{abstract}
Da'ie is an important group in the spreading of Islam during the period of sultanate of Brunei and Sulu before British Colony Era. The domination of sultanates has given a positive impact to the spread of da'wah in Sabah (known as North Borneo). The da'i have succeeded to bring a harmonious spiritual need among the locals in Sabah. Islamisation has encouraged comprehensive way of life from legal, economy and politic aspects. This dynamic nature is shown through the effort of Islamisation. It can be seen with the acceptance of Islam from the local community of Sabah (North Borneo); who lived in east coast through the influence of Sultanate of Sulu and flourishing in the west coast of Sabah through the Sultanate of Brunei. Therefore, this study aims to identify the da'wah methods that are a factor to Islamization in Sabah. The design of this study is a literature review with using content analysis of the materials on the study topic. The findings show that there are five methods of da'wah that were highlighted in Islamization in Sabah before the British era. It is an adaptation of the preacher to local life, approaching the ruling class, through marriage and through trade activities, and the factor of the superiority of the sufi preachers.
\end{abstract}

Keywords: Method of da'wah, Islamization, Sabah, before 16th century 


\begin{abstract}
Abstrak
Golongan pendakwah merupakan kumpulan penting dalam penyebaran Islam di zaman kesultanan Brunei dan Sulu sebelum era penguasaan British. Penguasaan kesultanan tersebut telah memberikan kesan positif terhadap perkembangan dakwah di Sabah (dikenali Borneo Utara). Kumpulan pendakwah dilihat berjaya membawa suatu keperluan rohani secara harmoni dengan masyarakat tempatan di Sabah. Pengislaman telah mendorong kepada bentuk kehidupan beragama yang menyeluruh dari aspek perundangan, ekonomi dan politik. Ia dapat dilihat dengan penerimaan Islam masyarakat tempatan Sabah (Borneo Utara) yang tinggal di kawasan pantai timur melalui pengaruh Kesultanan Sulu dan berkembang di kawasan pantai barat Sabah melalui pengaruh Kesultanan Brunei. Oleh itu, kajian ini bertujuan untuk mengenal pasti metod-metod dakwah yang menjadi faktor kepada pengislaman di Sabah sebelum era penguasaan British. Reka bentuk kajian ini adalah kajian literatur dengan menggunakan analisis kandungan terhadap bahan-bahan bertulis mengenai topik kajian. Dapatan kajian menunjukkan terdapat lima metod dakwah yang diketengahkan dalam pengislaman di Sabah sebelum penguasaan British iaitu penyesuaian dengan corak kehidupan tempatan, mendekati golongan pemerintah, melalui perkahwinan dan melalui kegiatan perdagangan, dan faktor kelebihan golongan pendakwah sufi.
\end{abstract}

Kata kunci: Metod dakwah, pengislaman, Sabah, sebelum abad ke-16

\title{
Pendahuluan
}

Metod ialah suatu sistem mengenai kaedah dan prinsip-prinsip tertentu dalam melaksanakan sesuatu perkara. ${ }^{1}$ Dalam Kamus Dewan edisi keempat, metod bermaksud suatu kaedah atau cara dalam melakukan sesuatu perkara. ${ }^{2}$ Ini menunjukkan metod adalah suatu kaedah, cara dan suatu sistem dalam melaksanakan sesuatu perkara. Istilah dakwah pula bermaksud mengajak atau menyeru kepada Islam. ${ }^{3}$ Menurut 'Abd al-Karīm Zaydān, dakwah ialah suatu usaha yang membawa atau menyeru manusia kepada akidah Islam dan jalan kehidupan yang jelas (bashīrah). ${ }^{4}$ Sayyīd Quṭb menjelaskan bahawa jalan kehidupan yang jelas adalah agama

BBC English Dictionary (London: Harper Collins Publisher, 1993), 700.

2 Kamus Dewan Edisi Keempat (Kuala Lumpur: Dewan Bahasa dan Pustaka, 2007), 328.

3 Al-Mu'jam al-'Arabiyy al-Asāsiyy (Larousse: Al-Munazzhamah al'Arabiyyah li al-Tarbiyyah wa al-Thaqāfah wa al-'Ulūm, 1989), 452.

4 'Abd al-Karīm Zaydān, Usūl al-Da'wah (Beirut: Al-Risālah Publisher, 1998), 5. 
Islam yang tidak terdapat sebarang keraguan. ${ }^{5}$ Bahi el-Khuly menyatakan dakwah merupakan suatu proses atau pemindahan umat daripada suatu lingkungan kepada suatu lingkungan yang lain, iaitu daripada kekufuran kepada Islam, kesesatan kepada hidayah, kejahatan kepada kebaikan dan unsur-unsur negatif. ${ }^{6} \mathrm{Al}-$ Alūry menyifatkan proses ini meliputi usaha mencerahkan pandangan atau fikiran dan akal manusia kepada aqidah yang benar, atau maslahat yang memberi manfaat kepada manusia serta melepaskan daripada kesesatan dan musibah yang melingkari manusia. ${ }^{7} \mathrm{Al}-$ Qardhawi menjelaskan dakwah bertujuan membawa pandangan hidup manusia mengikut petunjuk agama dengan mengkhususkan perhambaan diri kepada Allah s.w.t, melepaskan diri daripada țaghhùt yang terpaksa dipatuhi, memberi hak kepada orang yang ditentukan haknya oleh Allah, dan menafikan haknya ke atas orang yang dinafikan haknya oleh Allah, amar ma'ruf nahi mungkar serta berjihad ke jalan-Nya. ${ }^{8}$

Berasaskan maksud-maksud di atas, dapat dinyatakan metod dakwah adalah suatu kaedah atau cara menyeru manusia kepada agama Islam, usaha membawa manusia kepada ajaran Islam dan cara memperkenalkan atau menarik perhatian serta menyeru manusia kepada kebenaran Islam. Dalam al-Quran, Allah s.w.t telah menjelaskan mengenai metod dakwah dengan cara hikmah (al-hikmah), nasihat yang baik (al-maw'izah al-hasanah) dan dengan perbincangan, dialog dan perbahasan yang terbaik (almujādalah). Firman Allah dalam surah al-Naḥl, ayat 125 yang bermaksud:

"Serulah ke jalan Tuhanmu (wahai Muhammad) dengan hikmah kebijaksanaan dan nasihat pengajaran yang baik, dan berbahaslah dengan mereka (yang engkau serukan itu) dengan cara yang lebih baik; sesungguhnya Tuhanmu Dialah jua yang lebih mengetahui akan orang yang sesat dari jalanNya, dan Dialah jua yang lebih mengetahui akan orangorang yang mendapat hidayah petunjuk."

5 Sayyid Quṭb, Fi Zilāl al-Qur'ān (Kaherah: Dār al-Shurūq, 1985), 4:2034.

6 El-Bahi El-Khuly, Panduan Para Pendakwah, terj., Ismail Mohd Hassan (Terengganu: Yayasan Islam Terengganu, 1984), 4.

7 Adām 'Abd Allāh al-Alūry, Tārīkh al-Da'wah ilā Allāh Bayna al-Ams wa al-Yawm (Kaherah: Maktabah Wahbah, 1979),17-18.

8 Yūsuf al-Qarḍāwī, Thaqāfah Dā'iyyah (Beirut: Muassasah al-Risālah, 2001), 5 . 
Dalam konteks ini, pengislaman mempunyai hubungan signifikan terhadap keberksanan metod dakwah. Pengislaman bermaksud perbuatan mengislamkan, menjadikan orang lain memeluk atau menerima Islam dan menjadikan orang lain patuh atau menerima kepada peraturan yang terkandung di dalam ajaran Islam. Dalam bahasa Arab, pengislaman disebut yuslimu yang yang bermaksud patuh, mematuhi agama Islam dan memeluk Islam. ${ }^{9}$ Ibn Kathir menyatakan yuslim yang berasal daripada kalimah 'aslam' bermaksud menyerah diri, tunduk dan patuh kepada agama Allah. ${ }^{10}$ Ini menunjukkan istilah pengislaman merujuk kepada maksud 'aslam' yang bererti menerima Islam, dan memeluk Islam dengan beribadah kepada Allah serta tunduk patuh segala perintah-Nya. Pengislaman dilihat tidak terhad kepada perkara asas-asas akidah yang menentukan keislaman seseorang, tetapi meliputi segala kepatuhan peraturan terhadap agama Islam dalam kehidupan manusia.

Dalam bahasa Inggeris, pengislaman disebut Islamization yang maksud proses mengislamkan. Dalam kamus Collins English Dictionary, Islamization bermaksud memeluk atau mengislamkan sesuatu patuh kepada ajaran Islam. ${ }^{11}$ Dalam kamus The World Book Dictionary, Islamization bermaksud menjadikan seseorang itu beragama Islam. ${ }^{12}$ Dalam kamus English Dictionary Penguin, Islamization bermaksud untuk menjadikan sesuatu itu Islam, menjadikan seseorang itu Islam dan menjadikan sesuatu bertepatan dengan peraturan Islam. ${ }^{13}$ Ini menunjukkan pengislaman bukan tertumpu kepada pemelukan agama Islam sahaja, bahkan pematuhan kepada ajaran Islam dan mengislamkan sesuatu perkara dalam aspek kehidupan manusia seperti cara hidup, peraturan dan sebagainya.

Islamization telah diterima penggunaannya dalam bahasa Melayu dengan sebutan 'Islamisasi.' Islamisasi bermaksud suatu usaha dan proses menjadikan sesuatu patuh kepada ajaran Islam,

9 Al-Mu'jam al-'Arabiyy al-Asāsiyy, 638.

10 Ismā'īl bin 'Umar Ibn Kathīr, Shahih Tafsir Ibnu Katsir, terj. Al- Shaikh Shafiyyurahman Mubarakfuri (Jakarta: Pustaka Ibnu Katsir, 2013), 3:281.

11 Collins English Dictionary (Glasgow: Harper Collins Publishers, 1994), 818.

12 Clarence L. Barnhart \& Robert K. Barnhart The World Book Dictionary, ed. (Chicago: World Book Inc.,1988), 1118.

13 English Dictionary (London: Penguin Reference, 2001), 743. 
proses menerapkan nilai-nilai Islam ke dalam sesuatu bidang, dan perihal mengislamkan atau pengislaman. Istilah Islamisasi digunakan oleh Ismā'̄ill al-Fārūq ${ }^{14}$ dan Syed Naquib al-Attas ${ }^{15}$ dalam membincangkan proses mengislamkan ilmu pengetahuan (Islamization of knowledge). Pengislaman dilihat sebagai suatu usaha ke arah mengislamkan atau disebut Islamisasi dan mengamalkan perintah Allah melalui syariat yang diturunkan. Ia bukan sahaja terhad kepada pemelukan agama Islam bahkan meliputi perkara yang berkaitan dengan kefahaman dalam pelaksanaan sistem syariat dalam kehidupan beragama.

Pengislaman lebih bersifat dinamik kerana tidak tertumpu kepada aqidah manusia bahkan meliputi kepada cara kehidupan yang mengikuti syariat. Ia bersifat penerimaan terhadap ajaran Islam melalui dakwah berterusan dalam membangunkan masyarakat dan kebudayaan. Ia juga boleh dilihat melalui peristiwa perjanjian Aqabah kedua dan kehadiran kelompok daripada Madinah yang tertarik kepada Nabi SAW dan agama Islam. ${ }^{16}$ Ibn Hishām menyebutkan di dalam al-Sìrah alNabawiyyah, terdapat empat kumpulan yang datang berjumpa dengan Nabi SAW semasa mengerjakan haji iaitu kumpulan yang hendak mengetahui dan memeluk Islam, kumpulan yang tidak setuju dengan Nabi SAW yang membawa ajaran Islam, umpulan yang membuat perjanjian dengan Nabi SAW untuk bersetuju dengan Islam, dan individu yang hendak menemui Nabi SAW dan ingin bersamanya. ${ }^{17}$ Ini menunjukkan pengislaman boleh dikaitkan dengan persetujuan seseorang menerima peraturan-peraturan Islam dalam kehidupan.

14 Islamization of Knowledge, General Principles and Work Plan (International Institute of Islamic Thought: USA, 1989), 1.

15 Adi Setia, "Tiga Pengertian 'Sains Islam': Ke Arah Usaha Penyedaran Semula Misi Pengislaman Sains dan Teknologi Menurut Kerangka Faham Syed Muhammad Naquib al-Attas" (Makalah Training of Trainers Kursus Falsafah Ilmu, Jabatan Pengajian Kemasyarakatan \& Kewarganegaraan, Fakulti Sains Kemanusiaan, Universiti Pendidikan Sultan Idris, 11 Febuari 2015), 12.

16 Safī al-Raḥmān al-Mubārakfūrī, Al-Rāḥiq al-Makhtūm, terj. Mohd Nor Long (t.tp.: t.p., t.t.), 147-149.

17 Husni Muhammad Ibrahim Ghithas, Al-Da 'wah Islāmiyyah fi 'Ahd Amīr alMukminin 'Umar bin al-Khattab Radi Allah anh (Beirut: Al-Maktab Islāmiyy, 1985), 43. 
Oleh itu, kajian-kajian berkaitan dakwah dan pengislaman di negeri Sabah sebelum era penguasaan British Crown Colony lebih tertumpu kepada aspek persejarahan di Kepulauan Melayu. Kedudukan geografi Sabah yang terletak di Borneo utara menunjukkan terdapat pengaruh terhadap dan pengislaman daripada kepulauan yang berhampiran. Kajian berkaitan penerimaan Islam oleh pengkaji seperti S.Q Fatimi, ${ }^{18}$ T.W Arnold, ${ }^{19}$ Cesar, ${ }^{20}$ Muhidin Yusin ${ }^{21}$ Bilcher Bala ${ }^{22}$ dan Masnon ${ }^{23}$ menyatakan era kesultanan di Nusantara telah memberikan kesan terhadap pendakwahan di negeri Sabah (dikenali Borneo Utara). Golongan pendakwah dikatakan memainkan penting dalam menjelmakan Islam melalui aspek kehidupan sehingga ia diterima oleh masyarakat tempatan dengan baik. Justeru kajian ini bertujuan untuk mengenal pasti metod-metod dakwah dalam pengislaman di Sabah sebelum era penguasaan British Crown Colony.

\section{Metod Dakwah dalam Pengislaman di Sabah Sebelum Abad Ke-16 \\ Di Nusantara, metod dakwah dalam pengislaman telah dilakukan} oleh golongan mubaligh daripada luar. ${ }^{24}$ Proses pengislaman masyarakat berkembang dengan memberi kesan yang besar kepada politik, ekonomi dan sosial di Kepulauan Nusantara. Justeru itu, pelbagai metod dakwah yang telah digunakan golongan

18 S.Q. Fatimi, Islam Comes to Malaysia (Singapura: Malaysian Sociological Research Institute Ltd., 1963), 39.

19 T.W Arnold, The Preaching of Islam (Lahore: Ashraf Publication, 1970), 403.

20 Cesar Adib Majul, Islam di Filipina, terj. Shamsuddin Jaapar (Kuala Lumpur: Dewan Bahasa dan Pustaka, 1988), 68.

21 Muhiddin Yusin, Islam di Sabah (Kuala Lumpur: Dewan Bahasa dan Pustaka, 1990), 4.

22 Bilcher Bala, Bazley Bee Basrah Bee dan Jakaria Dasan, "Pengaruh Kesultanan Brunei kepada Masyarakat Sabah," Utusan Borneo, 3 April 2008, 13.

23 Masnon Haji Ibrahim, Sejarah Perkembangan Islam di Brunei " dalam Islam di Brunei, Sabah dan Sarawak, ed. Ismail Mat (Kuala Lumpur: Penerbit Asiana, 1989), 4.

24 Kasim Hj. Mansur, "K-Dakwah dan Peranannya dalam Proses Islamisasi di Sabah" dalam Isu-Isu Sains Sosial dari Perspektif Islam, ed., Asmady Idris, Dzurizah Ibrahim dan Rahminah Muharam (Kota Kinabalu: Universiti Malaysia Sabah, 2003), 183. 
pendakwah dalam menyampaikan Islam kepada masyarakat tempatan sejak sebelum kemerdekaan. S.Q Fatimi dalam bukunya yang bertajuk 'Islam Comes to Malaysia' menyatakan kedatangan Islam di Nusantara mempunyai kaitan dengan pendakwah Islam yang berasal daripada India, China Parsi dan Arab. Pendakwah Islam telah memainkan peranan penting dalam pengislaman golongan pemerintah dan masyarakat tempatan di Nusantara. Ini bertepatan dengan salah satu teori yang dikemukakan oleh Cesar Adib Majul bahawa kedatangan Islam di Nusantara adalah berkait dengan teori mubaligh iaitu Islam tersebar dengan peranan pendakwah yang terdiri dari pedagang sebelum penguasaan British.

Terdapat dua aspek yang difahami dalam konsep pengislaman iaitu perubahan manusia daripada bukan beragama atau selain agama Islam kepada akidah Islam, sepertimana dakwah Nabi SAW yang telah membawa manusia daripada kegelapan kepada cahaya Islam. Nabi Muhammad SAW telah berjuang selama 13 tahun menyeru masyarakat musyrikin Makkah yang telah lama menyembah berhala atau patung yang diwarisi sejak dari zaman nenek moyang mereka. Ia adalah usaha menyeru manusia kepada keesaan Allah. Esposito ${ }^{25}$ menjelaskan pengislaman atau Islamisasi adalah proses transisi kepada agama Islam sama ada kemasukan manusia secara perseorangan ataupun memeluk Islam beramai-ramai. Di Nusantara, penerimaan Islam berkembang setelah pengislaman di kalangan pemerintah ketika itu. Pengislaman Raja Parameswara pada abad ke-15 telah memberi kesan yang besar kepada politik, ekonomi dan sosial masyarakat di Melaka. Parameswara yang menukar nama kepada Sultan Muzaffar Shah telah mengisytiharkan Islam sebagai agama rasmi Melaka. Beliau telah menguatkuasakan hukum Islam dalam perundangan, ekonomi dan sosial. ${ }^{26}$ Kedatangan Islam telah memberi kesan terhadap aspek falsafah kehidupan dengan mengubah pandangan hidup yang berpaksikan kepada soal khayal, dongeng, dewa-dewa dan lain-lain kepada alam akal fikiran dan

25 John L Esposito, Ensiklopedi Oxford, Dunia Islam Moden, terj., Eva. Y. N, Fremmy, S, et al. (Bandung: Pustaka Mizan, 2002), 2:366.

26 Ensiklopedia Islam (Kuala Lumpur: Malaysian Encyclopedia Research Center Berhad, 1998), 5:147-149. 
peraturan syariah. ${ }^{27}$ Keadaan ini bertepatan dengan apa yang telah dinyatakan oleh S.M Naquib al-Attas bahawa proses Islamisasi di Nusantara pada peringkat pertama (dari 578-805/1200-1400) berlaku dalam konteks individu dan pemimpin. ${ }^{28}$

Kedua, pengislaman dirujuk mengislamkan sistem kehidupan manusia selaras ajaran Islam. Usaha ini adalah untuk membawa manusia muslim mematuhi atau taat melaksanakan perintah Allah dalam kehidupan. Ia dilihat seolah-olah wujud proses pengislaman selepas Islam. Maksud ini menunjukkan pengislaman adalah suatu proses mengislamkan sistem kehidupan meliputi aspek sosial, ekonomi dan politik. S.M Naquib al-Attas menyatakan period ini membincangkan tranformasi 'semangat roh Islam' dengan penyebaran 'philosophical mysticism,' tasawuf dan ilmu kalam. Manakala period ketiga pula, Islamisasi berterusan dan selari dengan kedatangan barat (Eropah). ${ }^{29}$ Gambaran ini menunjukkan usaha pengislaman sentiasa berlaku setelah pengislaman diperingkat individu itu berlaku akibat dari jajahan Barat yang bersifat sekular dalam konteks umat Islam selepas kejatuhan pemerintahan Khalifah Uthmaniyyah. ${ }^{30}$

Dalam catatan sejarah, kedua-dua bentuk dalam pengislaman telah dikenal pasti khususnya dalam penyebaran dan penerimaan Islam di Nusantara. Kumpulan pendakwah atau mubaligh telah memainkan peranan penting dalam merubah kepercayaan masyarakat tempatan kepada akidah Islam dan membangunkan kehidupan beragama yang berteraskan syariat. Pelbagai metod dakwah yang digunakan pendakwah dalam pengislaman di Nusantara sebelum abad ke-16. Masyarakat telah menerima Islam sebagai agama dalam kehidupan mereka.

Badlihisham menjelaskan bahawa kajian Fatimi menunjukkan Islam telah tiba pada tahun 1204 ketika ia mula menguasai politik di Tanah Melayu. Kenyataan ini disokong

27 Dusuki Ahmad, Ikhtisar Perkembangan Islam (Kuala Lumpur: Dewan Bahasa dan Pustaka, 1986), 539-544.

28 Kasim Hj. Mansur, K-Dakwah dan Peranannya dalam Proses Islamisasi di Sabah, dalam Isu-Isu Sains Sosial dari Perspektif Islam, 183.

29 Kasim Hj. Mansur, K-Dakwah dan Peranannya dalam Proses Islamisasi di Sabah, dalam Isu-Isu Sains Sosial dari Perspektif Islam, 183.

30 Ismail al-Faruqi, Pengislaman Ilmu, terj., Mustafa Kasim (Kuala Lumpur: Dewan Bahasa dan Pustaka, 1991), 1-2. 
oleh Brian Harrison yang menyatakan bahawa ketika Portugis muncul pada 1511, Semenanjung Tanah Melayu, Jawa, Maluku, Sulawesi, Borneo, Mindanao dan Kepulauan Sulu di Filipina telah lama memeluk Islam. Menurut Van Leur, pengislaman telah tersebar luas di gugusan Kepulauan Melayu disebabkan oleh pembangunan bandar-bandar yang terletak berhampiran pelabuhan termasuklah Melaka, Pasai dan Acheh. Kemudian Islam menyerap masuk ke alam Melayu melalui undang-undang pemerintahannya. Terdapat bukti kukuh tentang hubung kait ini secara langsung dengan institusi raja yang sekaligus menunjukkan bahawa proses tersebut telah dipengaruhi oleh keadaan dan motif politik ketika itu. Dalam hal ini, Morrison menyatakan Islam telah menjadi medium perantara kepercayaan agama yang baru kepada pemerintah dalam menghapuskan penentang mereka. Penerimaan Islam oleh istana telah membantu proses penerimaan Islam dalam kalangan golongan rakyat bawahan. Dalam erti kata lain, penerimaan Islam oleh raja menyebabkan kaumnya turut mengikut memeluk Islam. ${ }^{31}$

Pengislaman Islam di Kepulauan Melayu menunjukkan terdapat beberapa faktor keberkesanan dalam metod dakwah yang digunakan oleh kumpulan pendakwah atau mubaligh. Pengkaji seperti T.W Arnold, S.Q Fatimi dan Majul Cesar juga mengakui peranan pendakwah-pendakwah yang mendekati masyarakat tempatan Nusantara di dan berjaya dalam pengislaman. Di samping itu, T.W Arnold mengakui Islam tersebar meluas di seluruh dunia hasil usaha gigih penganutnya yang mengaplikasikan pelbagai metod. Dakwah telah berkembang melalui kegiatan perdagangan, pendekatan tasawuf, aktiviti kesenian, polisi dan pentadbiran kerajaan. Pengislaman berlaku secara intensif apabila pemimpin yang mempunyai kedudukan tinggi dalam masyarakat memeluk Islam dan ini diikuti oleh para pengikut secara beramai-ramai. Sifat ketaatan pengikut yang tinggi kepada para pemimpin tempatan dimanfaatkan sepenuhnya oleh para pendakwah pada peringkat awal pengislaman. ${ }^{32}$

31 Badlihisham Mohd Nasir, "Islam dan Dakwah dalam Zaman Kebangkitan Awal Islam dan Era Penjajahan Barat di Tanah Melayu," Jurnal Islamiyyat, 34 (2012), 6-7.

32 Zulkiple Abdul Ghani, Dakwah dalam Alam Siber di Malaysia (Nilai: Penerbit USIM, 2014), 29. 
Selain itu, T.W Arnold turut menegaskan kejayaan awal dakwah di rantau ini disebabkan oleh tiga faktor utama iaitu peranan para pedagang Islam dari Arab dan India yang turut menjadikan dakwah sebagai aktiviti utama, menggunakan bahasa dan adat istiadat tempatan serta institusi perkahwinan dan mempu menonjolkan diri sebagai pemimpin, memperlihatkan akhlak terpuji yang lebih bertamadun di samping memastikan Islam menjadi 'agama kota' sebagai lambang kemajuan. Kualiti pendakwahan dalam tempoh berkenaan dianggap cukup penting. Pendakwah dikatakan amat memahami kaedah berdakwah serta dapat mengaplikasikannya secara penuh hikmah - iaitu melakukan sesuatu perkara yang sukar dengan penuh kemahiran dan berilmu serta memperoleh hasil yang berkualiti. ${ }^{33}$

Dalam konteks ini, penerimaan Islam di Sabah (dahulu dikenali Borneo Utara) telah dikaitkan dengan peranan penting kumpulan pendakwah di era pemerintahan kesultanan Brunei dan Sulu. Oleh itu, terdapat beberapa bentuk metod dakwah yang digunakan oleh golongan pendakwah dalam pengislaman di Sabah sebelum penguasaan British. Di antaranya adalah seperti berikut:

(a) Penyesuaian dengan Kehidupan Tempatan

T.W Arnold menyatakan bahawa pendakwah telah berjaya menguasai bahasa tempatan, budaya tempatan, berkahwin dengan orang tempatan dan mempunyai hubungan baik dengan ketua masyarakat. Penyesuaian ini telah memberikan suatu gambaran terhadap penerimaan keberadaan kumpulan pendakwah dalam kehidupan masyarakat tempatan sekalipun mempunyai perbezaan. Bahkan ia tidak menggambarkan suatu konflik dalam menerima penyesuaian. ${ }^{34}$

Begitu juga dalam pengislaman di Sabah, pendakwah telah memainkan peranan penting dalam mengasimilasikan elemen dakwah dengan kehidupan masyarakat tempatan. Antara pendakwah yang telah sampai di pulau-pulau di kepulauan Sulu ialah Sharif Karim al-Makhdum. Beliau telah pergi ke sebahagian besar pulau-pulau di Nusantara untuk memperkenalkan Islam. Pada tahun 1380, terdapat masjid di

\footnotetext{
33 Zulkiple Abdul Ghani, Dakwah dalam Alam Siber di Malaysia, 29.

34 T.W Arnold, The Preaching of Islam (Lahore: Ashraf Publication, 1970), 402.
} 
Buansa yang telah dibina oleh Sharif Karim al-Makhdum. Pusara beliau telah ditemui di pulau Sibutu. ${ }^{35}$ Gelaran 'makhdum' dikaitkan dengan ulama sufi yang mempunyai keistimewaan tertentu dan menjadi perhatian kepada penduduk tempatan. ${ }^{36}$ Manakala tokoh kedua yang dikaitkan dengan pengislaman di kepulauan Sulu ialah Abu Bakar. Beliau merupakan pendakwah yang pernah tiba di Melaka dalam perjalanan menuju ke Palembang dan Brunei. Beliau tiba di kepulauan Sulu pada tahun 1450 dan berjaya membina sebuah masjid.

Pemerintah juga telah memberikan pengiktirafan kepada Abu Bakar di Buansa. ${ }^{37}$ Ini menunjukkan masyarakat tempatan menerima peranan pendakwah dalam kehidupan mereka dan memberikan kedudukan tinggi dalam hierarki sosial. Dian dalam memetik tulisan Hermansyah yang bertajuk 'Islam dan Melayu di Воrneo' menjelaskan tentang bagaimana cara hidup Islam dihubungkan dengan kehidupan masyarakat tempatan di Borneo. Pendakwah telah membawakan model baru dengan mengasimilasikan budaya dan praktis agama melalui nilai-nilai Islam yang mudah. Penerimaan perubahan ini dianggap seperti memberikan model baru yang lebih dinamik berbanding kehidupan mereka sebelum ini. ${ }^{38}$ Keadaan ini turut disebutkan oleh Zulkiple Abd Ghani ${ }^{39}$ yang menyatakan bahawa masyarakat Nusantara melihat Islam sebagai 'agama kota' mempunyai nilainilai ketamadunan yang unggul ketika itu. Golongan pendakwah telah berjaya membawa suatu model kehidupan Islam dengan bentuk asimilasi budaya dan agama yang dilihat sebagai suatu cara kehidupan yang lebih bertamadun dalam masyarakat.

Penyesuaian metod dakwah berasaskan kehidupan agama dan budaya tempatan juga menarik perhatian pengkaji Barat. S.Q Fatimi dalam memetik tulisan John Crawfurd di 'The Journal of

35 T.W Arnold, The Preaching of Islam, 403.

36 Muhiddin Yusin, Islam di Sabah (Kuala Lumpur: Dewan Bahasa Dan Pustaka, 1990), 8.

37 T.W Arnold, The Preaching of Islam, 414.

38 Dian Kartika Sari, "Islam and Malay in Borneo: Review Article," Journal Al-Albab 5, (2016), 54.

39 Zulkiple Abdul Ghani, Dakwah dalam Alam Siber di Malaysia, 33 
the Indian Archipelago and Eastern Asia,' mendapati antara faktor kejayaan pendakwah Islam adalah membawakan suatu bentuk penyesuaian agama dengan kehidupan masyarakat tanpa konflik di Nusantara; ${ }^{40}$

"The success of the Mahomedan missionaries contrasted with the failure of the Christian, it is not difficult to trace to the cause. The Arabs and the other Mahomedan missionaries conciliated the native of the country, - acquired their language - followed their manners - intermarried with them and, melting into the mass of the people, did not, on the one hand, give rise to privileged race, nor on the other, to a degraded caste. Their superiority of intelligence and civilization was employed only for the instruction and conversion of a people, the current of whose religious opinions was ready to be directed in any channel into which it was skillfully diverted. They were merchants as well as the Europeans, but never dreamt of having recourse to the iniquitous measure of plundering the people of the produce of their soil and industry. This was the cause which led to the success of the Mahomedans, and it was naturally the very opposite course which led to the defeat of the Christians."

(b) Pendakwah Mendekati Golongan Pemerintah

Pendakwah telah memainkan peranan pengislaman golongan pemerintah yang memberikan kesan positif terhadap perkembangan Islam. Adib Majul dalam bukunya 'Islam di Filipina, ${ }^{41}$ menyatakan pengislaman dalam kalangan pemerintah sebagai alat politik yang membolehkan pedagang luar menikmati perlindungan daripada pemerintah. Bahkan dikaitkan dengan andaian teori ekonomi yang bersifat spekulatif di atas penguasaan perdagangan di kepulauan Nusantara. T.W Arnold pula menyatakan antara faktor pengislaman di Kepulauan Nusantara adalah kejayaan pendakwah membina hubungan baik dengan pemerintah. ${ }^{42}$ Maka boleh dinyatakan bahawa pendakwah turut

\footnotetext{
40 S.Q. Fatimi, Islam Comes to Malaysia (Singapura: Malaysian Sociological Research Institute Ltd., 1963), 83-84.

41 Cesar Adib Majul, Islam di Filipina, terj. Shamsuddin Jaapar (Kuala Lumpur: Dewan Bahasa \& Pustaka, 1988), 68.

42 T.W Arnold, The Preaching of Islam, 365.
} 
mendapat keistimewaan tertentu setelah pengislaman pemerintah. Walaupun demikian, pengislaman golongan pemerintah telah memberikan impak positif terhadap Islam dan dakwah. Umpamanya, pengislaman Parameswara merupakan kemuncak kepada proses kegiatan dakwah di Melaka. Di atas faktor itu, perkembangan dakwah terus berkembang dengan dengan luas di Nusantara. Antara kesan lain daripada pengislaman pemerintah Melaka ketika itu adalah menjadikan undang-undang Islam yang dikenali Kanun Melaka dalam pemerintahan. ${ }^{43}$

Pada abad ke-10, penerimaan Islam telah dikenal pasti di beberapa kawasan Borneo Utara ${ }^{44}$ Menurut Suraya Sintang, agama Islam telah tersebar di empat penjuru utama negeri Sabah. Pertama di kawasan pantai Barat Selatan yang dipengaruhi oleh perkembangan Islam di Brunei. Kedua, di kawasan pantai Timur Sabah (Lahad Datu, Semporna dan Kinabatangan) yang dipengaruhi oleh perkembangan Islam di Selatan Filipina. Ketiga, di kawasan penempatan orang Tidong dan Bolongan yang dipengaruhi oleh perkembangan Islam di Kalimantan dan Makasar. Keempat, di kawasan penempatan orang Sungai dan Kadayan yang ditemui oleh pengkaji Barat, John White Head yang menemui Borneo dan mendapati penganut Islam di situ berbeza dengan penganut Islam di Brunei. ${ }^{45}$

Penulis sejarah juga berpendapat pengislaman melalui pengaruh kesultanan Brunei dan Sulu yang pernah menguasai Borneo termasuk Sabah (Borneo Utara). ${ }^{46}$ Borneo Utara asalnya adalah tanah jajahan Kesultanan Brunei. Pada tahun 1704, Sultan Brunei telah menyerahkan jajahan di Borneo Utara kepada Sultan Sulu sebagai membalas jasa di atas bantuan menewaskan pemberontakan dalam wilayahnya. Walaupun tidak terdapat buktibukti bertulis mengenai penyerahan ini, namun ahli sejarah berpendapat Borneo Utara adalah hak milik Kesultanan Sulu

43 Abdul Halim El-Muhammady, "Tasawwur Islam" Dinamika Dakwah: Satu Perspektif dari Zaman Awal Islam hingga Kini (Kuala Lumpur: Penerbit Universiti Malaya, (1992), 174-176.

44 Muhiddin Yusin, Islam di Sabah, 3.

45 Suraya Sintang, "Penganutan Agama Islam dan Kristian di Kalangan Masyarakat Kadazandusun Sabah,” Jurnal Usuluddin (2003), 67-68.

46 Muhiddin Yusin, Islam di Sabah (Kuala Lumpur: Dewan Bahasa Dan Pustaka, 1990), 3. 
semenjak awal abad ke-18. ${ }^{47}$ Manakala pengislaman melalui pengaruh Indonesia melalui Kalimantan kurang dikenal pasti. Kalimantan yang terletak di kepulauan Borneo pernah mempunyai kerajaan Islam pada abad ke-16 seperti di Sambas, Sukadana dan Landak di sebelah pantai barat Borneo. ${ }^{48}$ Namun peranan pendakwah daripada kerajaan tersebut kurang dikaitkan dengan pengislaman di Borneo Utara (Sabah) kecuali selepas penguasaan British.

Ketika zaman penguasaan Kesultanan Brunei, golongan pendakwah-pedagang banyak memainkan peranan dalam usaha dakwah dan pengislaman termasuk golongan pemerintah. Pengislaman pemerintah telah memberikan kesan kepada penyebaran Islam ke atas rakyat yang berada di bawah wilayah penguasaan. ${ }^{49}$ Catatan sejarah telah menunjukkan penduduk di beberapa kawasan pantai Barat Sabah seperti Weston, Kuala Penyu, Sipitang, Membakut dan Papar yang telah menerima Islam melalui kesultanan Brunei di akhir abad ke-15 dan 16. Begitu juga dengan kawasan-kawasan di Pantai Barat Sabah yang berhampiran Brunei. Ini terbukti dengan terdapat segolongan besar orang yang berketurunan Brunei sehingga kini yang dikenali sebagai Islam asal sehingga hari ini. Sebahagian besar mereka menjadi majoriti penduduk di beberapa kawasan Islam di kawasan Papar, Sipitang, Membakut, Menumbuk dan lain-lain. Keturunan mereka dikatakan berperanan sebagai pembawa Islam dan menyebarkan Islam kepada penduduk tempatan khususnya di kalangan suku kaum Bisaya yang banyak menduduki di kawasan tersebut. ${ }^{50}$

Agama Islam dikatakan diterima golongan pemerintah di Brunei lebih awal sejak abad ke-15 dan 16. Ketika itu Brunei dikenali nama Pu-Ni. ${ }^{51}$ Pengislaman di Sabah telah dikaitkan

47 Nik Anuar Nik Mahmud, Tuntutan Filipina ke atas Borneo Utara (Bangi: Penerbit UKM, 2009), 16.

48 S.Q. Fatimi, Islam Comes to Malaysia (Singapura: Malaysian Sociological Research Institute Ltd., 1963), 39.

49 Farid Mat Zin dan Anwar Fakhri Omar, "Amalan Tarekat di Kalangan Ulama Nusantara: Kajian Terhadap Ulama Kalimantan Indonesia," dalam Dakwah Tarekat Tasawuf di Malaysia: Relevansi dan Cabaran, ed., Zulkiple Abd Ghani \& Ahmad Redzuwan Mohd Yunus (Bangi: Jabatan Pengajian Dakwah dan Kepimpinan, UKM, 2004), 115-116.

50 Muhiddin Yusin, Islam di Sabah, 3.

51 Muhiddin Yusin, Islam di Sabah, 3-4. 
dengan duta utusan Pu-Ni (Brunei) pada tahun 977 ke China yang diketuai oleh P'u Ali. Pada tahun yang sama seorang pedagang bernama P'u Lu'hsieh tiba di muara sungai Pu-Ni dari China. Nama P'u disandarkan dengan istilah Arab yang berbunyi 'Bu' atau 'Abu' yang bermaksud bapa. Nama sebenar P'u Ali ialah Abu Ali dan P'u Lu'hsieh ialah Abu Lais. ${ }^{52}$ Menurut Hughes-Hallet, raja Brunei yang pertama memeluk Islam ketika itu ialah Mohammad Shah@ Awang Alak Betatar. Beliau telah memerintah Brunei pada abad ke-15. Berkemungkinan Pu-Ni telah menerima Islam kira-kira empat abad sebelum itu (abad ke-15) kerana orangorang Islam dari $\mathrm{Pu}-\mathrm{ni}^{53}$ telah sampai ke kawasan pantai barat Sabah sebelum abad tersebut. Namun penerimaan Islam oleh penduduk tempatan di kawasan-kawasan berkenaan dipercayai hanya bermula selepas Kesultanan Brunei memeluk Islam. ${ }^{54}$ Pengislaman golongan istana di Brunei dikatakan mempunyai pengaruh besar kepada perkembangan Islam melalui pendakwahpendakwah daripada Sukadana yang terletak di Kalimantan Barat. Namun pengislaman golongan istana di Brunei juga dikatakan mempunyai pengaruh dengan pendakwah dari Sukadana yang terletak di Kalimantan Barat. Golongan istana telah diislamkan Tuan Sheikh Shamsusu'd-din ${ }^{55}$ dengan membawa hadiah alQuran, sebentuk cincin daripada Makkah dan surat kebesaran daripada Sultan Muhammad Safi al-Din. ${ }^{56}$

Semasa pemerintahan Sultan Brunei ketiga iaitu Sultan Sharif Ali (1425-1432), baginda telah memainkan penting dalam penyebaran Islam ke seluruh rantau Nusantara termasuk Borneo Utara (Sabah). Sultan Sharif Ali turut dikenang sebagai 'Sultan Berkat' kerana jasanya yang telah membina masjid pertama dan membina struktur Kota Batu. Begitu juga semasa pemerintahan Sultan Bolkiah, baginda telah memainkan peranan secara tidak langsung dalam menyebarkan Islam di seluruh Kepulauan Borneo, Sulu dan Filipina dengan menggalakkan rakyat berhijrah ke

52 S.Q. Fatimi, Islam Comes to Malaysia, 67-68.

53 Pu-Ni ialah Brunei yang terletak di kawasan pantai barat Pulau Borneo dan berhampiran dengan Sabah.

54 Muhiddin Yusin, Islam di Sabah, 5-6.

55 Bilcher Bala, Bazley Bee Basrah Bee \& Jakaria Dasan, "Pengaruh Kesultanan Brunei kepada Masyarakat Sabah," Utusan Borneo, 3 April, (2008), 13.

56 T.W Arnold, The Preaching of Islam, 391. 
kawasan subur untuk dijadikan penempatan baru. ${ }^{57}$ Faktor tersebut telah menyebakan ramai penduduk Islam Brunei berhijrah dan berinteraksi dengan orang-orang tempatan di kawasan baru diterokai.

Semasa pemerintahan Kesultanan Sulu pula, pengislaman pemerintah telah memberikan kesan positif terhadap dakwah kepada masyarakat tempatan di Borneo Utara khususnya di kawasan pantai timur. Ini disebabkan kawasan pesisir pantai merupakan lokasi penting perdagangan dan menjadi tumpuan pendakwah-pedagang. ${ }^{58}$ Wilayah Borneo Utara kaya dengan arang batu, rotan dan mutiara yang terletak di kawasan strategik bagi pedagangpedagang Islam dari kepulauan Sulu. Hubungan perdagangan ini telah membawa kepada pengislaman dalam kalangan pemerintah Sulu. Terdapat sumber sejarah yang menyatakan bahawa Islam diterima di Sabah pada abad ke-15 melalui penduduk tempatan yang berketurunan suku Idahan di kawasan Lahad Datu iaitu bahagian pantai timur Sabah yang berhampiran Kepulauan Sulu. Bahagian ini pernah dikuasai oleh kesultanan Sulu khususnya di kawasan pantai timur yang meliputi sebahagian Sabah. ${ }^{59}$

Tarsila atau silsilah Sulu mencatatkan Islam telah tiba di kepulauan Sulu melalui peranan pendakwah (masha'ika atau makhdum) dan kegiatan perdagangan. Kegiatan perdagangan di wilayah Kesultanan Sulu telah membuka lembaran kepada pengislaman di pulau-pulau wilayah Filipina. Pengislaman di kepulauan Sulu dikaitkan dengan kedatangan kapal-kapal dagang Arab dari Ma-i ke Canton pada tahun 982. Ma-i (Moyi) ialah sebuah pulau di Filipina yang dipercayai Mindoro dan berhampiran dengan Borneo. Pada abad ke-15 dan 16, Kesultanan Sulu telah berjaya mendirikan institusi-institusi Islam melalui Sultan Syarif al-Hashim. Agama Islam telah tersebar dari kawasan pantai ke kawasan pergunungan dan di

57 Bilcher Bala, Bazley Bee Basrah Bee dan Jakaria Dasan, "Pengaruh Kesultanan Brunei kepada Masyarakat Sabah," Utusan Borneo, 5.

58 Samuel Bryan Scott, "Mohammedanism in Borneo: Notes for a Study of the Local Modifications of Islam and the Extent of Its Influence on the Native Tribe," Journal of the American Oriental Society, 33 (1913), 310.

59 Muhiddin Yusin, Islam di Sabah, 6. 
bahagian pedalaman. Hubungan politik dan perdagangan yang semakin meningkat di Kepulauan Sulu dan menjadi sebahagian Dār al-Islām di Nusantara. ${ }^{60}$

(c) Metod Dakwah melalui Perkahwinan

Perkahwinan adalah satu metod dalam dakwah. Sebelum penguasaan British di Sabah, golongan pendakwah-pedagang dikatakan mengahwini anggota keluarga pemerintah dan telah memainkan peranan politik yang agak penting melalui pemerintahan. Tuan Masha'ika merupakan orang yang membawa masuk unsur-unsur keislaman dan membina keluarga Islam dalam keluarga pemerintah. ${ }^{61}$ Perkahwinan pendakwah-pedagang dengan kerabat pemerintah telah memberikan kesan yang penting kepada pengislaman rakyat secara tidak langsung. Terdapat hubungan keturunan yang menggunakan gelaran-gelaran dengan silsilah orang Arab di Nusantara sehingga hari ini seperti al-Saggaf, alAttas, al-Idrus dan sebagainya. Masyarakat Melayu-Arab (Syed dan Sharifah) dikenal pasti dengan hubungan perkahwinan di antara orang Arab dan orang tempatan yang datang untuk berdagang sebelum era penjajahan Eropah. Contohnya, di daerah Tawau terdapat beberapa perkampungan atau penempatan yang pernah dikenali dengan sebutan kampung Arab disebabkan kebanyakan penduduk berbangsa Arab dan sebahagian kecil bangsa Suluk. ${ }^{62}$

Mengikut tarsila Sulu, Tuan Mashaika merupakan orang telah mengahwini kerabat pemerintah. Beliau telah berkahwin dengan anak perempuan Raja Sipad. Perkahwinan dengan anak perempuan Raja Sipad telah membuka suatu dinasti baru dalam pemerintahan Sulu. Beliau juga digelar Tuan Syarif Aulia iaitu seorang pengajar yang mulia. ${ }^{63}$ Seorang lagi pendakwah yang dikaitkan dengan perkembangan dakwah di kepulauan Sulu melalui perkahwinan ialah Abu Bakar. Beliau telah berkahwin dengan anak raja Buansa, Raja Baginda. Abu Bakar telah dilantik

\footnotetext{
60 Cesar Adib Majul, Islam di Filipina, 90-91.

61 Cesar Adib Majul, Islam di Filipina, 98.

62 Mohamad Shauki Mohd Radzi et al., "Masyarakat Arab (Keturunan Syed) di Tawau, Sabah: Tinjauan Terhadap Sejarah Pertapakan dan Sumbangan dari Aspek Sosial," Borneo Research Journal 1 (2007), 194.

63 Cesar Adib Majul, Islam di Filipina, 102.
} 
takhta sebagai pewaris kepada pemerintahan Buansa dan telah memperkenalkan pentadbiran serta perundangan di Sulu dengan ajaran Islam. ${ }^{64}$

Dalam pengislaman di kawasan Maguindanao, segelintir golongan pendakwah dikatakan membina keluarga melalui perkahwinan dengan penduduk tempatan. Ikatan perkahwinan telah mempercepatkan proses pengislaman penduduk dari sudut kuantiti secara tidak langsung. Golongan diraja seperti pemerintah Sulu, Maguindanao dan Ternate turut mempunyai ikatan perkahwinan. Di atas faktor tersebut, golongan pendakwah khususnya ulama Arab tiba di wilayah tersebut sebagai pengajar, pedagang dan sebagainya. ${ }^{65}$ Perkembangan dakwah mereka di wilayah tersebut turut mempengaruhi penerimaan Islam di kawasan Borneo secara tidak langsung.

(d) Metod Dakwah melalui Kegiatan Perdagangan

Kegiatan perdagangan orang Islam telah menarik perhatian golongan pemerintah dan masyarakat tempatan di Sabah. Sebilangan pengkaji menyatakan kegiatan perdagangan menyumbang kepada penerimaan Islam melalui jalan laut. Teori penyebaran Islam melalui jalan laut telah diterima oleh pengkaji sejarah pertapakan Islam di Nusantara. Penemuan artifak, tanah perkuburan orang Islam dan kediaman orang Islam di kawasan pesisir laut telah menguatkan teori tersebut. Di atas faktor tersebut, terdapat sebahagian pengkaji yang mengaitkan pendakwah dan perdagangan kerana pemain dalam perdagangan ketika itu adalah sebahagian golongan pendakwah.

Menurut Adib Majul pengislaman penduduk tempatan di bawah wilayah Kesultanan Brunei dan Sulu dikaitkan dengan kegiatan perdagangan yang di dominasi orang-orang Islam yang berasal daripada Tanah Arab, Cina, Parsi dan lain-lain. 'Teori perdagangan' yang dikemukakan oleh sebilangan pengkaji sejarah telah merujuk kepada peranan yang dimainkan oleh pedagangpedagang Islam yang membawa agama Islam bersama dengan barangan dagangannya. ${ }^{66}$ Dalam hal ini, S.Q Fatimi turut mengulas tentang penelitian A.H Johns yang mendakwa orang

\footnotetext{
64 T.W Arnold, The Preaching of Islam, 412.

65 Cesar Adib Majul, Islam di Filipina, 105.

66 Cesar Adib Majul, Islam di Filipina, 88.
} 
Islam yang berdagang bukanlah semestinya penyebar agama Islam melainkan saudagar tersebut terdiri dari golongan dan lazimnya diketuai oleh para 'sheikh., ${ }^{67}$

Mereka telah meneroka kawasan-kawasan strategik di Nusantara untuk tujuan perdagangan dan dakwah. Pemusatan perdagangan muslim lebih memudahkan dan menjamin dalam setiap aktiviti transaksi yang dilakukan. Menurut Bilcher Bala et al., pengislaman pemerintah Brunei pada awal abad ke-15 telah menyumbang kepada kegiatan perdagangan yang hebat dan menjadi sebuah pelabuhan enterport mewah di Nusantara. Pedagang-pedagang Islam mula berpengaruh luas di rantau ini. Kegiatan perdagangan di Brunei telah menarik perhatian masyarakat tempatan terhadap Islam secara tidak langsung. ${ }^{68}$

Pedagang Islam yang berasal daripada Tanah Arab dikatakan lebih banyak menjalinkan hubungan perdagangan dengan daerahdaerah di Nusantara. ${ }^{69}$ Pedagang-pendakwah dikatakan berkeupayaan memiliki kapal dan mempunyai pengetahun geografi yang tinggi. ${ }^{70} \mathrm{Di}$ atas faktor tersebut, Van Leur menulis dalam disertasi yang bertajuk 'On Early Asian Trade' menyatakan Islam telah diterima melalui kegiatan perdagangan yang di bawa pedagang Islam. Orang-orang tempatan akan berhubung dengan pedagang luar untuk mendapatkan barangan dagangan yang dibawa. ${ }^{71}$

Selain nilai akhlak yang ditonjolkan pedagang Islam dianggap sebagai mewakili suatu kebudayaan yang tinggi. Mereka mempunyai kewibawaan ekonomi, pelayaran laut, pernah berada dalam kerajaan yang unggul dan mempunyai keistimewaan dengan golongan pemerintah atau keluarga pembesar di atas ikatan 'persaudaraan Islam'. ${ }^{72}$ Menurut Mohamad Shaukhi Mohd Radzi et al., faktor ekonomi mempengaruhi pedagang Islam datang ke

67 Badlihisham Mohd Nasir, "Islam dan Dakwah dalam Zaman Kebangkitan Awal Islam dan Era Penjajahan Barat di Tanah Melayu," Jurnal Islamiyyat, 34 (2012), 6.

68 Bilcher Bala, Bazley Bee Basrah Bee \& Jakaria Dasan, "Pengaruh Kesultanan Brunei kepada Masyarakat Sabah," Utusan Borneo, 3 April 2008, 3.

69 S.Q. Fatimi, Islam Comes to Malaysia, 79.

70 Zulkiple Abdul Ghani, Dakwah dalam Alam Siber di Malaysia, 34.

71 Cesar Adib Majul, Islam di Filipina, 68.

72 Cesar Adib Majul, Islam di Filipina, 68. 
Sabah. Seperti yang diketahui bahawa pedagang Islam terkenal dengan urusan perdagangan atau urusniaga. Kedudukan Borneo Utara yang strategik telah dijadikan tempat persinggahan dalam pelayaran berulang-alik dari selatan Filipina dan Palembang, Sumatera. ${ }^{73}$ Ini menunjukkan kegiatan perdagangan orang-orang Islam memberikan suatu gambaran dinamik yang menarik dan mempengaruhi. Ia turut diperkenalkan dengan nilai budaya orang Islam dalam perdagangan yang sentiasa mementingkan nilai akhlak seperti dituntut ajaran agama.

(e) Metod Dakwah melalui Golongan Sufi

Sebahagian pengkaji sejarah berpendapat antara faktor yang mempengaruhi pengislaman di Sabah ialah tuntutan amanah agama atau dakwah yang kebanyakannya digerakkan oleh golongan sufi. Teori mubaligh golongan sufi memainkan peranan penting dalam pendakwahan dan pengislaman di Nusantara. Menurut Adib Majul, golongan pendakwah atau mubaligh sufi bukan hanya dengan kegiatan perdagangan sahaja. Malahan mereka terlibat memberikan khidmat pendidikan, perkahwinan dengan orang tempatan, di kepulauan Sulu. ${ }^{74}$

Al-Ṭusi dalam kitabnya al-Lumā' menyatakan golongan sufi sangat menitikberatkan akhlak mulia, pembersihan jiwa (tazkiyyah al-nafs) dan berusaha untuk mempertingkatkan martabat mereka dengan amalan-amalan Mahyudin yang mempunyai kelebihan. Mereka melaksanakannya menurut petunjuk Nabi SAW dan para sahabatnya serta orang-orang yang mengikut jejak langkah mereka dan kesemua ini ilmunya terdapat dalam kitab Allah. ${ }^{75}$ Yahya pula menyatakan gerakan dakwah golongan ahli sufi telah bermula dengan kedatangan Ismā‘̄̄l al-Ṣiddīq dan Fakīr Muhammad dari Makkah sekitar tahun 1260-an. Menjelang abad ke-16 dan 17 lahir ulama-ulama sufi yang terkenal dan memberi sumbangan besar

73 Mohamad Shauki Mohd Radzi et al., "Masyarakat Arab (Keturunan Syed) di Tawau, Sabah: Tinjauan Terhadap Sejarah Pertapakan dan Sumbangan dari Aspek Sosial," 196.

74 Cesar Adib Majul, Islam di Filipina, 69

75 Khairuddin Mohd Amin, "Sumber Aliran Al-Tasawuf Al-Sunni Menurut Islam," dalam Dakwah Tarekat Tasawuf di Malaysia: Relevansi dan Cabaran, ed. Zulkiple Abd Ghani dan Ahmad Redzuwan Mohd Yunus (Bangi: Jabatan Pengajian Dakwah dan Kepimpinan, UKM, 2004), 168. 
dalam pemerintahan, politik dan pendidikan umat Islam sehingga di Asia Tenggara. ${ }^{76}$

Golongan sufi juga dikatakan mempunyai 'faktor kelebihan' yang digunakan dalam kegiatan kemasyarakatan dan kebajikan sebelum abad ke-16. Mereka dikenali sebagai pendakwah daripada golongan sufi atau tasawuf. Menurut Wahyu Hidayat et al., faktor kelebihan yang dikaitkan oleh pendakwah golongan sufi banyak mempengaruhi dalam kehidupan beragama melalui kitab-kitab pengajian di Nusantara. ${ }^{77}$ Manakala S.Q Fatimi juga menyatakan faktor kelebihan golongan sufi dikaitkan dengan perkara ajaib:

"...would have us believe that Islam miraculously spread through the magical powers of the makhdums and maulanas who came from "the regions above the wind."

Ini menunjukkan keistimewaan pendakwah sufi menjadi faktor tarikan bagi penduduk tempatan memeluk Islam. Dalam tarsila Sulu menyebutkan penduduk dari kawasan berhampiran telah datang beramai-ramai kepada pendakwah sufi. Antara kesan yang boleh dikenal pasti ialah terdapat kepercayaan keramat seperti kubur-kubur lama yang dianggap keramat di kawasan perkampungan orang Islam asal. Kubur-kubur lama yang dianggap keramat di kawasan perkampungan orang Islam asal seperti di Papar, Lahad Datu, Kimanis dan sebagainya adalah kepunyaan 'syarif'. Gelaran 'syarif' adalah tokoh-tokoh tertentu yang pernah berada di Sabah suatu ketika dahulu dan dipercayai mempunyai keistimewaan dari sudut kerohanian. Mereka dikaitkan dengan amalan-amalan kelebihan yang sering digambarkan mempunyai unsur-unsur luar biasa. Faktor ini merupakan tarikan yang membolehkan seseorang menerima Islam disebabkan dengan keadaan masyarakat setempat yang hidup bersandarkan kepercayaan kuasa ghaib, magis dan sebagainya. Penerimaan

76 Md. Yusof Abd. Hamid, "Perjuangan dan Jihad Tokoh-tokoh Tarekat Tasawuf di Nusantara," dalam Dakwah Tarekat Tasawuf di Malaysia: Relevansi dan Cabaran, ed. Zulkiple Abd Ghani dan Ahmad Redzuwan Mohd Yunus (Bangi: Jabatan Pengajian Dakwah dan Kepimpinan, UKM, 2004), 103.

77 Wahyu Hidayat Abdullah, Muhammad Mustaqim Mohd Zari dan Abd Hadi Borham, "The Influence of al-Sahihayn on Popular Hadith Literatures: The Case of Khazinah al-Asrar Jalilah al-Adhkar," Global Journal of alThaqafah 7 (2017), 29-37.

78 S.Q. Fatimi, Islam Comes to Malaysia, 79. 
Islam dalam keadaan sedemikian menjadikan agama Islam bertapak dan seterusnya mengalami proses perkembangan sendiri dalam kalangan masyarakat. ${ }^{79}$

Kedatangan Sharif Awliya Karim al-Makhdūm iaitu seorang ulama yang dipercayai menyebarkan Islam kepada penduduk tempatan Sulu pada tahun 1380 telah menarik perhatian masyarakat tempatan dan turut dikaitkan dengan unsur-unsur luar biasa.80 Dalam tarsila Sulu, pengaruh golongan makhdūm dan maulana sebagai mubaligh telah berjaya mengislamkan masyarakat tempatan sama ada di peringkat pemerintah atau rakyat. Sharif Karim al-Makhdum dipercayai orang yang mulamula memperkenalkan Islam di Sulu, khususnya di kawasan Buansa. Beliau digelar dengan 'Tuan Syarif Aulia' iaitu seorang mubaligh atau pengajar. Malah keperibadian makhdum telah memberi kesan terhadap penerimaan Islam di kalangan masyarakat tempatan. Terdapat tarsila yang menyatakan bahawa makhdum berjalan di atas permukaan air, bercakap dengan kertas, terbang di udara, menyelamatkan orang lemas, dan digambarkan dengan kuasa 'magis' terutamanya di Bengal. Francisco Combes turut mengakui bahawa terdapat kuasa-kuasa 'magis' di kalangan mereka yang membawa masuk Islam di Filipina dan turut menarik perhatian golongan istana atau pemerintah. ${ }^{81}$

Metod dakwah golongan sufi juga digambarkan memenuhi hasrat rohani masyarakat tempatan Nusantara yang berlatarbelakangkan kepercayaan animisme, pagan dan lain-lain. Amalan sufi telah mengubah falsafah kehidupan masyarakat tempatan, dari pandangan hidup yang berpaksikan kepada soal khayal, dongeng, dewa-dewa dan lain-lain kepada alam akal fikiran dan peraturan syariah. Kehadiran golongan sufi telah mendapat tempat di kalangan masyarakat tempatan disebabkan keistimewaan dan kebolehan golongan sufi sebagai ulama-ulama Islam yang mempunyai hubungan erat dengan nilai kepercayaan mereka. Selain dapat memenuhi keperluan kerohanian mereka, ianya turut memberi kekuatan terhadap kebenaran Islam. ${ }^{82}$

\footnotetext{
79 Muhiddin Yusin, Islam di Sabah, 2-3.

80 Muhiddin Yusin, Islam di Sabah, 3.

81 Cesar Adib Majul, Islam di Filipina, 76.

82 Muhiddin Yusin, Islam di Sabah, 8.
} 


\section{Penutup}

Secara keseluruhannya, terdapat lima metod dakwah yang telah dibincangkan dalam pengislaman sebelum era penguasaan British di Sabah (Borneo Utara). Pertama, metod dakwah dilakukan pendakwah khususnya golongan sufi yang menyesuaikan dengan corak kebudayaan tempatan. Penyesuaian ini berlaku dengan harmoni dan tanpa konflik. Kedua, pendakwah mendekati golongan pemerintah yang memberikan kesan pengislaman raja dan rakyat di bawah wilayahnya. Penguasaan kesultanan Brunei dan Sulu secara de facto ke atas sebahagian wilayah Sabah (Borneo Utara) telah memberikan kesan positif kepada pengislaman rakyat di bawah pemerintahan. Sistem di bawah pemerintahan atau jajahan Brunei dan Sulu telah memberikan kesan penting dalam penyebaran Islam termasuk di kawasan negeri Sabah. Walaupun demikian, pengaruh ini berlaku di kawasan tertentu sahaja tanpa menyeluruh disebabkan tiada gerakan dakwah yang tersusun dikenal pasti. Hanya melalui galakan pemerintah dalam penyebaran Islam di kawasan-kawasan di bawah penguasaan masing-masing. Ketiga, pendakwahpedagang telah menggunakan metod dakwah melalui perkahwinan dengan kerabat pemerintah dan penduduk tempatan. Hubungan perkahwinan telah membentuk suatu dinasti dalan sebuah kerajaan Islam yang memberi pengaruh dan meningkatkan kuantiti orang Islam berkembang secara tidak langsung. Keempat, metod dakwah melalui kegiatan perdagangan telah menarik perhatian golongan pemerintah dan masyarakat tempatan kepada agama Islam. Kelima, metod dakwah golongan sufi yang terdiri daripada mereka yang digelar sheikh dan makhdum telah memainkan peranan penting dalam penyebaran Islam di Sabah. Sebahagian mereka dikaitkan dengan unsur-unsur yang bersifat karamah, luar biasa dan magis yang menarik perhatian masyarakat tempatan menerima Islam. Secara keseluruhannya, empat metod dakwah dalam pengislaman yang dibincangkan telah berterusan mempengaruhi corak dan keutuhan kehidupan beragama masyarakat Islam dalam aspek akidah, ibadah dan akhlak di Sabah sekalipun berhadapan cabaran era penguasaan British Crown Colony (1846) dan Chartered Company (BNBCC) (1881) yang bermotifkan ekonomi, sekularisasi dan missionari. 


\section{Bibliografi}

Abdul Halim El-Muhammady. Tasawwur Islam Dinamika Dakwah: Satu Perspektif dari Zaman Awal Islam hingga Kini. Kuala Lumpur: Penerbit Universiti Malaya, 1992.

Adi Setia. "Tiga Pengertian 'Sains Islam': Ke Arah Usaha Penyedaran Semula Misi Pengislaman Sains dan Teknologi Menurut Kerangka Faham Syed Muhammad Naquib alAttas." Makalah Training of Trainers Kursus Falsafah Ilmu, Jabatan Pengajian Kemasyarakatan dan Kewarganegaraan, Fakulti Sains Kemanusiaan, Universiti Pendidikan Sultan Idris, 11 Febuari, 2015.

Al-Alūry, Adām 'Abd Allāh. Tārīkh al-Da 'wah ila Allāh bayna al-Ams wa al-Yawm. Kaherah: Maktabah Wahbah, 1979.

Al-Mu'jam al-'Arabiyy al- Asāsiyy. Larousse: Al-Munazzhamah al-'Arabiyyah li al-Tarbiyyah wa Thaqāfah wa al-'Ulūm, 1989.

Al-Qarḍāwī, Yūsuf. Thaqāfah Dā'iyyah. Beirut: Muassasah alRisālah, 2001.

Arnold. T.W. The Preaching of Islam. Lahore: Ashraf Publication, 1970.

Badlihisham Mohd Nasir. "Islam dan Dakwah dalam Zaman Kebangkitan Awal Islam dan Era Penjajahan Barat di Tanah Melayu." Jurnal Islamiyyat 34 (2012), 6-14.

BBC English Dictionary. London: Harper Collins Publisher, 1993.

Bilcher Bala, Bazley Bee Basrah Bee dan Jakaria Dasan. "Pengaruh Kesultanan Brunei kepada Masyarakat Sabah," Utusan Borneo, 3 April 2018.

Cesar Adib Majul. Islam di Filipina, terj. Shamsuddin Jaapar. Kuala Lumpur: Dewan Bahasa dan Pustaka, 1988.

Clarence L. Barnhart \& Robert K. Barnhart. The World Book Dictionary, ed. Chicago: World Book Inc., 1988.

Collins English Dictionary. Glasgow: Harper Collins Publishers, 1994.

Dian Kartika Sari. "Islam and Malay in Borneo: Review Article." Journal Al-Albab 5 (2016), 54-61.

Dusuki Ahmad. Ikhtisar Perkembangan Islam. Kuala Lumpur: Dewan Bahasa Dan Pustaka, 1986.

El-Bahi El-Khuly. Panduan Para Pendakwah, terj. Ismail Mohd Hassan. Terengganu: Yayasan Islam Terengganu, 1984. 
English Dictionary. London: Penguin Reference, 2001.

Ensiklopedia Islam jil. 5. Kuala Lumpur: Malaysian Encyclopedia Research Center Berhad, 1998.

Esposito, John L. Ensiklopedi Oxford, Dunia Islam Moden, jil. 2, terj., Eva. Y. N, Fremmy, S, et al. Bandung: Pustaka Mizan, 2002.

Farid Mat Zin dan Anwar Fakhri Omar. "Amalan Tarekat di Kalangan Ulama Nusantara: Kajian Terhadap Ulama Kalimantan Indonesia," dalam Dakwah Tarekat Tasawuf di Malaysia: Relevansi dan Cabaran, ed., Zulkiple Abd Ghani dan Ahmad Redzuwan Mohd Yunus, Bangi: Jabatan Pengajian Dakwah dan Kepimpinan, UKM (2004), 115-116.

Ibn Kathīr, Ismā'īl bin 'Umar, Shahih Tafsir Ibnu Katsir, jil. iii, terj. Shafiyyurahman Al-Mubarakfuri. Jakarta: Pustaka Ibnu Katsir, 2013.

Islamization Of Knowledge, General Principles and Work Plan. International Institute of Islamic Thought: USA, 1989.

Ismail sl-Faruqi. Pengislaman Ilmu, terj. Mustafa Kasim. Kuala Lumpur: Dewan Bahasa dan Pustaka, 1991.

Kamus Dewan Edisi Keempat. Kuala Lumpur: Dewan Bahasa dan Pustaka, 2007.

Kasim Hj. Mansur. "K-Dakwah dan Peranannya dalam Proses Islamisasi di Sabah" dalam Isu-Isu Sains Sosial dari Perspektif Islam, ed., Asmady Idris, Dzurizah Ibrahim dan Rahminah Muharam. Kota Kinabalu: Universiti Malaysia Sabah, 2003.

Khairuddin Mohd Amin. "Sumber Aliran Al-Tasawuf al-Sunni Menurut Islam," dalam Dakwah Tarekat Tasawuf di Malaysia: Relevansi dan Cabaran, ed. Zulkiple Abd Ghani dan Ahmad Redzuwan Mohd Yunus, 2004.

Masnon Haji Ibrahim. Sejarah Perkembangan Islam di Brunei." dalam Islam di Brunei, Sabah dan Sarawak, ed. Ismail Mat. Kuala Lumpur: Penerbit Asiana, 1989.

Md. Yusof Abd. Hamid. "Perjuangan dan Jihad Tokoh-tokoh Tarekat Tasawuf di Nusantara," dalam Dakwah Tarekat Tasawuf di Malaysia: Relevansi dan Cabaran, ed. Zulkiple Abd Ghani \& Ahmad Redzuwan Mohd Yunus. Bangi: Jabatan Pengajian Dakwah dan Kepimpinan, UKM, 2004. 
Mohamad Shauki Mohd Radzi et al. "Masyarakat Arab (Keturunan Syed) di Tawau, Sabah: Tinjauan Terhadap Sejarah Pertapakan dan Sumbangan dari Aspek Sosial.” Borneo Research Journal 1, (2007) 194-216.

Muhiddin Yusin. Islam di Sabah. Kuala Lumpur: Dewan Bahasa dan Pustaka, 1990.

Nik Anuar Nik Mahmud. Tuntutan Filipina ke Atas Borneo Utara. Bangi: Penerbit UKM, 2009.

Quṭb, Sayyid. Fi Zilal al-Qur'ān. Kaherah: Dār al-Shurūq, 1985.

S.Q. Fatimi. Islam Comes to Malaysia. Singapura: Malaysian Sociological Research Institute Ltd., 1963.

Samuel Bryan Scott. "Mohammedanism in Borneo: Notes for a Study of the Local Modifications of Islam and the Extent of Its Influence on the Native Tribe." Journal of the American Oriental Society, 33 (1913), 310-328. https://doi.org/10.2307/592838

Suraya Sintang. "Penganutan Agama Islam dan Kristian di Kalangan Masyarakat Kadazandusun Sabah,' Jurnal Usuluddin 18 (2003), 59-80

Wahyu Hidayat Abdullah, Muhammad Mustaqim Mohd Zarif dan Abd Hadi Borham. "The Influence of al-Sahinhayn on Popular Hadith Literatures: The Case of Khazinah al-Asrār Jalīlah al-Adhkār." Global Journal of al-Thaqafah 7 (2017), 29-37.

Zaydān 'Abdul Karīm. Usūl al-Da'wah. Beirut: Al-Risālah Publisher, 1998.

Zulkiple Abdul Ghani. Dakwah dalam Alam Siber di Malaysia. Nilai: Penerbit USIM, 2014. 